\title{
A COMPARATIVE STUDY BETWEEN TELEGRAM AND WHATSAPP IN RESPECT OF LIBRARY SERVICES
}

\author{
Rubi Acherjya Manna \\ Library Assistant, Academy of Technology, Hooghly, India \\ Dr. Shyamal Ghosh \\ Librarian, Academy of Technology, Hooghly, India
}

\begin{abstract}
Library system concepts have been changed fully in modern digital era. Library 2.0, Marketing of Library, Ubiquitous Library are the modern concepts in Library field by the use of Social Networking Site (SNS) like Facebook, Twitter, Whatsapp, Telegram etc. Library needs to develop its services to satisfy its user demands and promote its facilities by modern technology to reach itself to its user. Here we have given an outline of Whatsapp and Telegram, comparison between both of these in respect of modern Library services to understand better service provider Apps in highly demand with better facilities.
\end{abstract}

Key words: Whatsapp, Telegram, SNS Services, Telegram Library, Library Services.

Cite this Article: Rubi Acherjya Manna and Dr. Shyamal Ghosh, A Comparative Study Between Telegram and Whatsapp In Respect of Library Services. International Journal of Library \& Information Science, 7(2), 2018, pp. 1-5. http://iaeme.com/Home/issue/IJLIS?Volume=7\&Issue=2

\section{INTRODUCTION}

In our modern tech-society, library needs to update day to day to provide better services to its users. Now a day many people used to wake up with Social Networking Site (SNS) like Facebook, Twitter, Whatsapp, Telegram etc. Here we discuss about application of SNS in Library and try to draw a comparison between Whatsapp and Telegram to understand the best application apps to provide better library services. Through these messaging apps Library can provide all required services instantly and effectively. Library 2.0 and 24 x 7 concept can be served by these Instant Messaging Apps, very efficiently. 


\section{REVIEW OF LITERATURE}

Ansari and Tripathi (2017) conducted an online survey to measure usability of Whatsapp for service delivery in the libraries and found use of Whatsapp can improve alerting services with other services. Ghaemi and golshan (2017) had made an experiment to understand the impact of Telegram on teaching vocabulary among Iranian Intermediate EFL (English as Foreign Language) learners and found a positive effect on students' by the use of SMS via social networks as a teaching tool. Asnafi...[et al.] (2017) examine the use of Telegram Messenger as a mobile-based social network in Iranian academic libraries from March 2016 to May 2016 and found mobile based services had a significant influence on academic libraries. Manna and Ghosh (2017) studied that application of Whatsapp technology in Library Services. They also show the process of whatapp installing, group creating and working in several application in libraries. Ebrahimpour [et al.](2016) focused on the effect of Social Networks on the educational relationship among the students and universities on 1000 students at 7 medical universities of Iran in 2015. They found that $85 \%$ used daily Social Networks of which Telegram used most and it help in improvement of the scientific relation level. Ansari and Hasan (2015) has discussed in his paper, named Use of Social Networking Sites in Library and Information Centre, about Social Networking Sites and its impacts in LIS field. With the help of SNS Library promote its services and develop its proficiency. Olaniyi (2015) had discussed the features and facilities of Whatsapp in academic libraries to easily send real time messages of individual or group who used library in free of cost. These facilities can provide anytime, anywhere required. He illustrated the process of implementation of Whatsapp in libraries. Jadhay (2014) described an exploratory study to examine academic librarians' views on using SNS for library collaboration. He also found the improvement in current networking and knowledge sharing practices between user and library professionals.

\section{SOCIAL NETWORKING SITE AND ITS IMPACT IN LIBRARY}

Social networking site can be defined as an internet or electronic gadget-based social space where people can connect, communicate, create and share content with others within a second. In respect of Library Services it enhance the ubiquitous (anytime, anywhere) quality to its user to provide better services. When it comes to Library field online it allows users to satisfy their requirement $24 \times 7$ and share ideas, activities, events and interests within the individual network. The concept of Library 2.0 means constantly updated library services and a provision of developing its facilities of services by user feedback and participation. The Library Marketing concept also fulfill by Social Networking Sites i.e.:

- Provide news or information for users on demand

- Provide links to recommended Internet Resources

- Book reviews, information about new books

- Provide news or information for librarians

- Guided in research and development

- Provide Current Awareness Services (CAS)

- Provide Reference and Referral Services

- Provide Community Information Services

\section{WHATSAPP AND TELEGRAM}

WhatsApp is a free messaging app for iPhone and other smart phones running on Android, iOS , Windows, Nokia S40, Nokia S60, BlackBerry, BlackBerry 10.It creates a user account using one's phone number as the username. WhatsApp Inc. was founded in 2009 by two former employees of Yahoo! Inc., Brain Acton and Jan Koum. There is no cost (not even 
yearly subscription charge) to use WhatsApp facilities internationally. WhatsApp uses phone's Internet connection (4G/3G/2G/EDGE or Wi-Fi, as available) to let message and call enlisted persons. Switch from SMS to WhatsApp to send and receive messages, calls, photos, videos, Voice Messages, pdf files, document, location etc.

Telegram is a free cloud-based messenger with seamless sync to access messages from several devices at a same time including tablets and computer. It is one of the web applications serving a large online community which was launched in 2013 by two Russian brothers, Pavel and Nikolai Durov. By this app users can send messages and exchange photos, videos, stickers, audio, and files of any type up to $1.5 \mathrm{~GB}$. It also provides Bot API by creating a new Bot using the telegram app one can control and easily build specialized tools for it, integrate any services. By multi-data center infrastructure and encryption this app is faster and more secure. This app is used to communicate between the people but also, we are able to control the devices which also read the status from sensors and are logged to twitter and Gmail.

\section{COMPARATIVE STUDY BETWEEN WHATSAPP VS TELEGRAM}

Both apps have very common features but some where some difference also available. Here we have given an outline in the following table for more illustration:

\begin{tabular}{|c|c|c|c|}
\hline \multicolumn{2}{|c|}{ Characteristics } & Whatsapp & Telegram \\
\hline \multicolumn{2}{|r|}{ Origin } & $\begin{array}{c}\text { WhatsApp Inc. was founded } \\
\text { in } 2009 \text { by two former employees } \\
\text { of Yahoo! Inc., } \\
\text { Brain Acton and Jan Koum }\end{array}$ & $\begin{array}{l}\text { Founded by Russian entrepreneur } \\
\text { Pavel Durov, in August } 2013 .\end{array}$ \\
\hline \multicolumn{2}{|c|}{ System supports } & Android, Linux, Windows & Andriod, Windows / Mac /Linux \\
\hline \multirow{23}{*}{ Features } & Bots & ( & Yes \\
\hline & Cloud-based & Yes : Required active internet on phone & Yes \\
\hline & End-to-End Encryption & Yes : by Default & Yes : via Secret Chat \\
\hline & File Sending capacity & Up to $100 \mathrm{MB}$ & Up to $1.5 \mathrm{~GB}$ \\
\hline & $\begin{array}{c}\text { Editing of Already Sent } \\
\text { Messages }\end{array}$ & No & Yes : Up to 48 hours \\
\hline & In-App Browser & No & Yes \\
\hline & Open API & No & Yes \\
\hline & Pass code lock & No & Yes \\
\hline & Public Channels & No & Yes \\
\hline & Public Groups & Up to 256 friends & Up to 75,000 friends \\
\hline & $\begin{array}{l}\text { Add member, Change } \\
\text { group name and photo }\end{array}$ & Only Admin & $\begin{array}{l}\text { In unrestricted mode (Any Group } \\
\text { Member) }\end{array}$ \\
\hline & $\begin{array}{c}\text { Members last visit } \\
\text { status }\end{array}$ & Always seen & $\begin{array}{l}\text { Optional (based on permission of } \\
\text { user) }\end{array}$ \\
\hline & Secret Chat & Yes : Encrypted by Default & Yes : Optional \\
\hline & Self-destruct Timer & No & Yes \\
\hline & $\begin{array}{l}\text { Notification of Secret } \\
\text { Screen shots taken }\end{array}$ & No & Yes \\
\hline & Sent Message Delete & Yes : Up to 7 minutes & Yes : Up to 48 hours \\
\hline & $\begin{array}{l}\text { Simultaneous Multi- } \\
\text { Device access }\end{array}$ & No & Yes \\
\hline & Stickers & No & Yes \\
\hline & Username & No & Yes \\
\hline & Video Calls & Yes & No \\
\hline & Web / Desktop version & Yes : Required active internet on phone & Yes \\
\hline & IFTTT integration & Disable & Enable \\
\hline & Tie-up with Facebook & Yes & No \\
\hline
\end{tabular}




\section{WHATSAPP AND TELEGRAM IN RESPECT OF LIBRARY SERVICES}

WhatsApp and Telegram changed the mental and physical appearance of peoples' life style. These are very useful tools to communicate and share information among a mass of people. Libraries can also use these technologies to improve their services. Libraries can provide a wide array of services to interested users by both of these Apps [8]:

- E-Journal and E-books (both text and audio) are accessible through these Apps.

- It provides location-based services, the internet/web-based OPAC on intranet

- Library tours, instruction/orientation programs have been quite significant in bringing the nonusers to libraries and also help the remotely located users.

- The Image Services in a library might offer a number of high quality, fee based photographic and document imaging services including digitized photographs, diagrams, maps, photos of places of national importance.

- It also provides the following services such as extension/inquiry, return information/inquiry, interlibrary loan requests, SDI service application, email service of academic journals, database use education application, etc.

- Users can read alerts, check records, renew resources, request items, track interlibrary loans and document delivery requests, set up future application and work in mobile library services through these apps.

- Information on job openings, varieties of scholarly competition, library events such as orientations program, book recall, lectures on special topic, news in relation to scholarly work, awards and so on can be given using mobile devices in order to update the user's knowledge short messages regarding the library events and news can be sent to the users personally through these applications.

- Users can get notified instantly with notice alerts on overdue books, outstanding fines, reminders to return library items, library event information, etc by these.

- Libraries can receive the suggestions from the users and also users can ask library professionals anything by the live chat.

- The reference services can be provided with the help of sending and receiving SMS. Immediate feedback is also possible from the user's side.

\section{CONCLUSION}

In the above study we have found Telegram is a cloud-based messenger with seamless sync. As a result, people can access their messages from several devices at once. We also found so many features are available in both communicative apps but if we look back to their characteristics we have seen many drawbacks available in Whatsapp (like its group member capacity, limited sending file size, no username facility, default secret chat, no bots option etc.) where as Telegram is very helpful for sending big file size like e-books, e-articles, audio video lectures to its end user. So, In case of library services Telegram is very helpful for sending information to communicate its users without any limitations in our modern techsociety. 


\section{REFERENCES}

[1] Ghaemi, Farid and Golshan, Niloofar Seyed. The Impact of Telegram as a Social Network on Teaching English Vocabulary among Iranian Intermediate EFL Learners. International Journal of Information and Communication Sciences. 2(5), 2017, 86-92

[2] Ansari, Aslam and Hasan, Mehfoozul. Use of social networking sites in library and information centers. In Library Information Science and Information Technology for Education. National Conference on August, 2015, 84-89. Retrieved from https://www.researchgate.net/publication/296241236. Retrieved on 28.02.2018

[3] Ansar, Mohd Shoaib and Tripathi, Aditya. Use of WhatsApp for Effective Delivery of Library and Information Services. DESIDOC Journal of Library \& Information Technology. 37(5), 2017, 360-365

[4] Olaniyi, A. R. WhatsApp: library application. 2015. Retrieved from http://www.academia.edu/17538132/Library_use_of_whatsapp. Retrieved on 28.02.2018.

[5] Jadhav, Vilas G. Application of Social Networking Services (SNS) for Library Collaboration: An Exploratory Study. International Research: Journal of Library \& Information Science. 4(1), 2014, 121-129.

[6] Asnafi, Amir Reza [et al.]. Using Mobile-Based Social Networks by Iranian Libraries: The Case of Telegram Messenger. Library Philosophy and Practice (e-journal), 2017. Retrieved from http://digitalcommons.unl.edu/libphilprac/1539 Retrieved on 28.02.2018

[7] Ebrahimpour, Alireza...[et al.]. The Effect of Social Networks on the Scientific Research Relations, Prospectiveness, Creativity and satisfaction of Scientific Position. International Journal of Medical Research \& Health Sciences. 5(7S), 2016. 413-418

[8] Manna, Rubi Acherjya and Ghosh, Shyamal. WhatsApp: a smart application in library services. In Towards Knowledge Society \& the role of Academic Libraries: problem and prospects. UGC Sponsored National Seminar on March 18, 2017, 136-143

[9] Clyde, Laurel A. (2004), Weblogs and Libraries, Chandos Publishing, UK.

[10] Murthy, P.N.V.S.N.; Rao S. Tejeswara and Rao, G. Mohana. Home Automation using Telegram. International Journal of Advanced Research in Computer and Communication Engineering. 6(6), 2017. 64-69

[11] Whatsapp vs Telegram: http://www.dignited.com/23969/whatsapp-vs-telegramfeature-feature-comparison/ Retrieved on 28.02.2018 